\title{
China English, a Developing Variety of English
}

\author{
Hui Yun ${ }^{1}$ \\ ${ }^{1}$ School of Foreign Languages, Linyi University, China \\ Correspondence: Hui Yun, School of Foreign Languages, Linyi University, Shandong, China, 276000. Tel: \\ 86-186-5399-8669. E-mail: cloud502@126.com
}

Received: January 20, 2013 Accepted: February 18, 2013 Online Published: February 22, 2013

doi:10.5539/ells.v3n1p117 URL: http://dx.doi.org/10.5539/ells.v3n1p117

\begin{abstract}
Nowadays, English can be seen or heard almost everywhere in many countries including China. With the arising of the English varieties, besides British and American ones, China English is argued by some scholars that it should be regarded as a variety of English, since it takes Standard English as its core, and can be used to express certain unique things relating to the Chinese society and culture (Li, 1993). China English is different from Chenglish or Chinese English, and it carries certain culture and society characters in many aspects and hardly can be replaced. China English has some syntactic and grammatical distinctions due to the influence of the Chinese language culture $(\mathrm{Hu}, 2004)$.
\end{abstract}

Keywords: China English, English variety, international language, culture

\section{Introduction}

\subsection{English Becomes the International Language}

The English language has been spreading all over the world due to the British political imperialism in the nineteen century and the American economic hegemony in the twentieth century (Crystal, 1997). English is now spoken in nearly every country and not only as a language of international diplomacy, science, business and education but also as an international language of communication in common life.

Nowadays the English language is no longer the language peculiar to native speakers but a language potentially belongs to the whole of humanity (Hu, 2004). The varieties of English are increasing with the wide spreading of English in the world. British English and American English, the two major standard varieties have become two of the many varieties (Kachru, 1997); however, other varieties begin giving full play to their role with their own features of vocabulary, sentence structure and grammatical logic (Hu, 2004), such as Canadian Variety, Indian Variety, Philippine Variety etc. Just as Brutt-Griffler (2002, p. ix) suggests, "the proliferation of varieties of English is a necessary result of the development of world English".

\subsection{The Arise of China English}

With the emerging of so many more varieties of English, "China English" has been being debated more than 20 years. It was first raised in 1980 by Ge (1983), a famous Chinese linguist and lexicographer (Cui, 2006; Kirkpatrick \& Xu, 2002). Ge (1983) argues that China English holds its own ground being a developing variety since China is engaged in more international issues and English is being generalized in China.

Being an English lecturer in China, in this paper, I intend to discuss the inevitability and necessity of the existence of China English based on the factors pertaining to the status of English, the characteristics of China English, its contribution to English, as well as the Chinese culture and contemporary Chinese society.

\section{English in China Today}

According to Kachru's (1997) famous three categories, presently China English belongs to the Expanding Circle, where English is learnt and used as a foreign language and is used for international communication rather than internal communication.

At present, the rise of English in China is phenomenal (Adamson, 2004). English is currently being learnt and used at various levels in the world's most populous country (Adamson, 2004); the estimated number of English learners and users in China is 300 million and the number is still increasing (Wen, 2009). English competence is a very crucial element for individuals to enter a higher school or apply for a good job. English is the compulsory 
subject for all of the students in the universities, colleges, secondary schools and it is also being offered in more and more primary schools (Cui, 2006). An increasing number of teachers take up the challenge of teaching through English because the "bilingual education" policy is becoming popular in many countries and which requires the teaching like science and maths of subjects in schools especially in secondary schools through the medium of English (Adamson, 2004 p. 3).

\section{Language Depends on Communicative Needs}

Platt, Weber \& Ho (1984) indicates that the development of a language variety depends on "communicative needs" (p.87) of those people who use it. The British or American English varieties used in other places may lack some words or phrase to express the local living, affairs, productions or other relative things out side of Britain or the U.S. In that case, new expressions of the English are demanded to fulfil the "communicative needs" and sometimes people use those in their local dialect or create new ones.

As an international language, English comprises varieties of English for specific aims (Widdowson, 1997). "The language change that has resulted in the development of varieties of English in such nations as Nigeria, India and Singapore is known collectively as the New Englishes. These varieties are also referred as the "indigenized Varieties of English" which have been documented in great details over the last two decades (Brutt-Griffler, 2002 p. 12; Kachru, 1985). These varieties of English being placed alongside other categories of English varieties the 'old' mother tongue American and British varieties, reflect the uniqueness of the nation conditions in which they arise and how they express the national culture (Brutt-Griffler, 2002; Kachru, 1990).

Smith (1976) also suggests that it is not necessary for non-native speakers to speak more like the native speakers because as an international Language, English is just used as a tool by people of different nations to communicate with one another (Smith, 1987). In China, English is used more by the Chinese to contact other speakers rather than the native speakers as in the daily life Chinese people have to communicate with the people from different countries all over the world rather than the people only from the English speaking countries. Therefore, Chinese speakers do not have to speak standard British or American English in the international communication. Moreover, China English contains irreplaceable local characters, and then it is the more suitable choice rather than other English varieties in the context of China.

\section{Chinglish}

We talk about Chinglish briefly before we interpret the term of China English. When we make mention of China English, many Chinese people may associate it with Chinglish because Chinglish had been a common phenomenon (Wei \& Fei, 2003) and which is more familiar than the term China English for the Chinese. In fact, China English and Chinglish are two totally different concepts although they are often confused by many people.

Chinglish is a Chinese-influenced variety, it refers to some fragmentary English linking which is translated from isolated Chinese words, especially from some idioms with the Chinese sentence structure. Such kind of English sounds very odd and often extremely confuses the foreigners on their meanings without considering the basic English grammatical structure, (Wei \& Fei, 2003). For example:

1. Good good study and day day up!

(Study hard and make progress everyday.)

2. No three no four!

(Dubious or shady character of people.)

3. Give you some colour see see!

(Teach you a lesson.)

These kinds of expressions were once very popular but now have been spumed and are only used for joking because they breach the essential language rules of English.

\section{China English}

\subsection{What Is China English?}

China English is a developing English variety in China (Kirkpatrick, and Xu, 2002), and as Li (1993) defines, it takes Standard English as its core, expressing unique things relating to the society and culture of China in different fields. Hu (2004) points out that the pronunciation of China English is close to Standard English. It can be well used as a communication tool although it has some syntactic and grammatical distinctions due to the influence of the Chinese language as well as some dissimilar lexis reflecting the Chinese Culture. 
To certain extent, we can say that China English plays a functional role both in China as well as in the world, and the concept of 'China English' has been accepted and recognized as a variety of English by many linguists and lexicographers such as Luo (1998), and Cui(2002).

\subsection{Characters of China English}

The Chinese and English languages belong to two completely dissimilar language families; the former is a part of Sino-Tibetan language family and the later is a part of Indo-European language family. Their modes of language logic, pronunciation, grammar and the writing are distinctive from each other. In China English, some linguistic habits of Chinese may often shift into English (Kachru, 1992). Influenced by the Chinese linguistic mode of thinking, China English has developed certain characteristics, especially in speech, in syntax which differ from Standard English. Three of them are shown as following: (Wei \& Fei, 2003)

1) Adverbial modifiers of time or place in China English are usually put at the beginning of a sentence instead of the end:

When I came in, he was watching TV. (Not 'He was watching TV when I came in.')

On the table, there is a pen. (Not 'There is a pen on the table.')

2) The open head structure rather than the extraposed structure is preferred in China English:

For him to complete the course work by next Tuesday is important.

(Not 'It is important for him to complete the course work by next Tuesday.')

To check the staff's names in the meeting is her duty.

(Not 'It is her duty to check the staffs name in the meeting.')

3) Chinese people are conditioned to give the response to the negative and tag questions based at the agreement or disagreement with the question itself rather than the fact:

"You can't leave the room without your mother's permission, can you?"

Chinese people would like to answer it with "Yes, I can't." or "No, I can." They are equivalent to "No, I can't" and "Yes, I can."

\section{Benefits for China English as an English Varity}

\subsection{China English Enriches English Language}

With the globalization of the world, as well as the interacting of the languages, China English enriches English domain as one of its varieties (Cui, 2006). A lot of loanwords from Chinese have been melted in English language family, such as kung fu, typhoon, feng shui, tai chi, ping pang. Such kind of words are widely approved and frequently used by people speak different varieties around the world. Cui (2006) suggests that according to Oxford English Dictionary online (2006), there are 3,561 word items root in Chinese.

It is hardly to replace a lot of English words which derive from China English because there are no equivalent words available in other varieties. Being replaced by force may cause misunderstanding. Most foreigners prefer jiaozi and toufu when they refer to Chinese food although there are other words as dumpling and bean curd with the similar meaning because jiaozi and tofu make people associate them with Chinese food immediately.

\subsection{China English Can Reflects Chinese Culture Well}

It is undoubted that as the carrier of culture, language is closely joined with the history and culture of its speakers (Cui, 2006). Culture influences and shapes Language, and language always reflects culture, thus language also represents people and people's approach to their ways of living and thinking since they are parts of culture (Jiang, 2000).

English Language undertakes the responsibility of transferring information between China and the world since Chinese, China's own language, is hardly used outside of China. Therefore, Chinese people do need an international language with Chinese characters for international communication, and then the English variety China English is suitable as English is the international language in the world.

That is what Ge (1980) indicates: when we want to express ourselves in both spoken or written English, we all have something to unique of about China to express. These express do not belong to those native speakers and they should be called China English (Ge, 1980).

China is a country with a vast territory and civilization of long standing so that it is impossible to present its 5,000 years' history and culture in English without any Chinese language factors. China English, as Li (1993) 
defined, relevantly reflects profound Chinese culture through the medium of English and can not be replaced by any others varieties even British and American varieties which have been regarded as the two standard ones (Hu, 2004). A huge number of Chinese traditional literatures can only be well expressed in China English rather than other varieties such as some terms Confucian, Taoism, Spring Festival and Four Books which are on the basis of Chinese culture deeply cannot be found correspondence words or expressions in other varieties.

\subsection{China English Can Avoid Some Cultural Misunderstanding}

Recently there is an interesting keen voice in China through internet, some linguistics as well as any people claim to substitute the word of "loong" (Chinese Dragon) for "dragon" in English (http://www.loong.com). The reason is that dragon refers to two quite different beasts in Chinese culture and western culture. Being an auspicious beast, dragon is an imagined beast in Chinese fables characterised with the camel's head, deer's horns, rabbit's eyes, bull's ears, snake's neck and trunk, carp's squama, eagle's claws. It is regarded as the totem of Chinese nation and Chinese people call themselves the descendant of the dragon. On the contrary, dragon in the western culture is a synonym for evil. In that case, it is liable for foreigners to contort its real meaning and this problem has been puzzling all of the Chinese people for ages. It is argued that confusion on understanding will decrease if we use Loong in stead of dragon to denote the beast.

Another similar entry like dragon is face, which occupies an important position in Chinese culture with plentiful meanings. It can mean "honour, dignity, pride, or even identity" (Hu, 2004, p. 28). Although in British English it also own the expression of lose face, for most other meaning are not commonly used.

\subsection{China English Reflects Current Chinese Society}

The lexicon of China English is being improved owe to the great changes in china these years and more updated words have been translating from Chinese into English. For example:

"Family contract responsibility system" refers to the key system in agriculture;

"Special economic zone" is one proper none from economic reform in the last 30 years.

"Individual economy" is two forms resulted from 'open-door policy'.

"One country, two systems" shows the relationship between the governments of China and Hong Kong, Macau (Cui, 2006, p. 42).

"Four modernizations" contains the modernization of industry, agriculture, science and technology (Hui, 2004. p. 28).

These terms hardly appear in other varieties since they are characterised with distinctive Chinese features. They aptly reveal the actual modern China to the world; they reflect the current Chinese political, economic system and make the main claims and policies known to all.

\section{Conclusion}

China English, which is based on Standard English but also retains Chinese cultural identity and Chinese ways of thinking, can be used by the Chinese for their own purpose (Cui, 2006) to contact with both native English speakers and non-native speakers in global circumstance. As China is taking part in more international affairs now, it is promoting China and the world to know each other much better than before. English teachers and learners should realize the irreplaceability of Chine English improve the developing of China English and try to perfect it and make it being known and accepted by the whole world.

Most material for English teaching in China are provided with the characters of China English and that redound to popularize China English since it is written and compiled by Chinese linguists. In addition, China English is becoming more effective along with the increasing formal and informal international intercourse and cooperation since China is much more active in the international political, economical and academic stages.

\section{References}

Adamson, B. (2004). China's English: A History of English in Chinese Education. Hong Kong: Hong Kong University Press.

Crystal, D. (1997). English as a global language. Cambridge: Cambridge University Press.

Cui, X. (2006). An understanding of 'China English' and the learning and the use of the English language in China. English Today, 88, 22(4), 40-43.

Ge, C. (1980). Issues of Translation from Chinese into English. Translation Journal, 2(22), July 2006.

Ge, C. (1983). On Translation from Chinese into English. Translation Theory and Translation Skills. China: 
China Translation publishing Company.

Hu, X. Q. (2004). Why China English, should stand alongside British, American, and the other 'world Englishes'. English Today, 78, 20(2), 26-33.

Jiang, W. (2000). The relationship between culture and language. ELT Journal, Oct., 54(4), 328-332. http://dx.doi.org/10.1093/elt/54.4.328

Kachru, B. B. (Ed.) (1992). The Other Tongue: English across cultures. Urbana: University of Illinois Press.

Kachru, B. B. (1997). Resources for Research and Teaching. In Smith, L., \& Forman, M. L (Eds.), World Englishes 2000. Honolulu: University of Hawaii Press.

Kirkpatrick, A., \& Xu, Z. (2002). Chinese pragmatic norms and 'China English'. World English, 21(2), 269-279. http://dx.doi.org/10.1111/1467-971X.00247

Li, W. Z. (1993). China English and Chinese English. Foreign Language Teaching and Research, 4, July 25, 2006.

Platt, J., Weber, H., \& Ho, M. L. (1984). The new Englishes. London: Routledge \& Kegan Paul plc.

Smith, L. (1976). English as an international auxiliary language. RELC Journal, 7(2). http://dx.doi.org/10.1177/003368827600700205

Smith, L. (1987). Discourse Across Cultures: Strategies in World Englishes. New York: Prentice Hall.

Wei, Y., \& Fei, J. (2003). Using English in China. English Today, 76, 19(2), 26-33.

Wen, J. (Premier of the State Council of the People's Republic of China) (2009, February 2). See China in the Light of Her Development. Speech at the University of Cambridge. China: Xinhua. Retrieved from http://www.loong.com 